\title{
MENGELOLA KONFLIK DALAM ORGANISASI UNTUK MENUNJANG EFEKTIVITAS KERJA KARYAWAN CV. ENIGMA
}

\author{
${ }^{1}$ Sri Mulyani, ${ }^{2}$ Anggada Bayu Seta, ${ }^{3}$ Siti Nurcahyati, ${ }^{4}$ Nurul Ilham, ${ }^{5}$ Roni Fadli \\ Dosen Fakultas Ekonomi Universitas Pamulang \\ Email : 1dosen02246@unpam.ac.id
}

\begin{abstract}
ABSTRAK
Konflik kerja adalah salah satu esensi dari kehidupan dan perkembangan yang terjadi pada setiap karyawan dalam menghadapi perubahan yang terjadi didalam lingkungan perusahaan. Karyawan selaku manusia memiliki perbedaan yang heterogen satu dengan yang lainnya seperti jenis kelamin, perasaan, strata sosial, ekonomi, agama, suku, budaya serta tujuan hidup yang berbeda inilah yang melatar belakangi timbulnya konflik. Mengingat begitu banyak faktor yang menyebabkan timbulnya konflik didalam suatu perusahaan, maka sudah sepatutnya setiap individu yang ada didalamnya mampu memahami konflik dan cara mengelolanya.

CV. Enigma merupakan perusahaan yang bergerak di bidang jasa otomotif. Dalam menjalankan tugasnya, CV. Enigma memiliki visi untuk menjadi perusahaan yang profesional dengan sumber daya manusia yang berkualitas serta sebuah misi yakni memberikan layanan kendaraan roda empat yang komprehensif. Untuk mencapai visi dan misi tersebut, hendaknya seluruh karyawan serta pimpinan yang ada didalamnya perlu memahami dan mengaplikasikan bagaimana cara mengelola konflik dengan baik guna meningkatkan efektivitas kerja.
\end{abstract}

\section{Kata Kunci : Konflik, Organisasi, Efektivitas Kerja}

\section{PENDAHULUAN}

"Organisasi adalah sekelompok orang yang bekerja sama dan saling bergantung untuk mencapai beberapa tujuan." Mc Shane dalam Andri dan Endang, (2015:24). Berdasarkan pengertian tersebut, dapat disimpulkan bahwa interaksi antara satu sama lain adalah hal yang sangat dibutuhkan di dalam suatu kelompok. Sebuah organisasi sepatutnya memiliki tujuan yang sama, dengan harapan semua orang yang ada didalam organisasi baik itu pemangku jabatan atau hanya sebagai anggota bisa selaras dalam melaksanakan fungsi organisasi.

Salah satu organisasi yang dimaksud adalah perusahaan, dimana di dalamnya terdapat karyawan dan pimpinan. Kelangsungan hidup suatu perusahaan dapat ditentukan dari kerjasama seluruh elemen yang ada didalamnya. Apabila kerjasama terjalin dengan baik, maka iklim organisasi yang tercipta adalah baik. Begitupun sebaliknya, apabila kerjasama yang terjalin tidak baik, maka iklim organisasi yang baik hanyalah angan belaka, karena kerjasama yang buruk akan menghasilkan suasana yang tidak kondusif didalam bekerja. Salah 
satu dampak buruk yang terjadi jika kerjasama tidak terjalin dengan baik adalah timbulnya konflik.

Stoner dan Wankel dalam Wahyudi, (2011:18), mengemukakan bahwa "Konflik organisasi merupakan ketidaksesuaian antara dua orang anggota organisasi atau lebih yang timbul karena fakta bahwa mereka harus berbagi dalam hal sumber daya yang terbatas, atau aktivitas-aktivitas pekerjaan dan atau karena fakta bahwa mereka memiliki status, tujuan, nilai-nilai persepsi yang berbeda".

Konflik kerja adalah salah satu esensi dari kehidupan dan perkembangan yang terjadi pada setiap karyawan dalam menghadapi perubahan yang terjadi didalam lingkungan perusahaan. Karyawan selaku manusia memiliki perbedaan yang heterogen satu dengan yang lainnya seperti jenis kelamin, perasaan, strata sosial dan ekonomi, agama, suku, budaya serta tujuan hidup yang berbeda inilah yang melatar belakangi timbulnya konflik.

Mengingat begitu banyak faktor yang menyebabkan timbulnya konflik didalam suatu perusahaan, maka sudah seharusnya pimpinan memberikan perhatian khusus dan memiliki kemampuan tentang manajemen konflik yang bertujuan untuk mencegah terjadinya gangguan terhadap karyawan dalam perusahaan, sehingga dapat fokus kepada visi dan misi organisasi. Criblin dalam Wahyudi, (2011:47), mengatakan "Manajemen konflik adalah teknik yang dilakukan oleh pimpinan organisasi untuk mengatur konflik dengan cara menentukan peraturan dasar dalam bersaing". Selanjutnya, menurut Wirawan, (2010:169), "Manajemen konflik sebagai proses pihak yang terlibat konflik atau pihak ketiga menyusun strategi konflik dan menerapkannya untuk mengendalikan konflik agar menghasilkan resolusi yang diinginkan"

CV. Enigma merupakan perusahaan yang bergerak di bidang jasa otomotif. Dalam menjalankan tugasnya, CV. Enigma memiliki visi untuk menjadi perusahaan yang profesional dengan sumber daya manusia yang berkualitas serta sebuah misi yakni memberikan layanan kendaraan roda empat yang komprehensif. Oleh karena itulah, seluruh karyawan serta pimpinan yang ada didalamnya perlu memahami dan mengaplikasikan bagaimana cara mengelola konflik dengan baik. Supaya visi dan misi perusahaan dapat tercapai.

\section{METODE PELAKSANAAN KEGIATAN}

1. Kegiatan pertama yang dilakukan adalah penyampaian sambutan oleh Ketua Pengabdian pada Masyarakat dan Kepala bagian kepegawaian CV. Enigma.

2. Dilanjutkan dengan pembacaan doa, serta ice breaking agar para peserta dapat lebih termotivasi dalam mengikuti penyuluhan yang akan diberikan oleh dosen-dosen Fakultas Ekonomi Universitas Pamulang.

3. Penyampaian materi mengenai konflik dan cara mengatasinya, kecerdasan emosi untuk mengelola konflik, serta cara bernegosiasi dan mencegah konflik.

4. Memainkan permainan simulasi dinamika kelompok dilanjutkan dengan membahas arti dari permainan tersebut.

5. Setelah pemberian materi terkait bagaimana cara mengelola konflik dalam organisasi dan simulasi dengan permainan, dilanjutkan dengan sesi tanya jawab 
antara dosen-dosen Universitas Pamulang dengan para peserta PkM.

6. Rangkaian kegiatan diakhiri dengan pembacaan doa penutup dan kemudian diakhiri dengan acara ramah tamah.

\section{HASIL DAN PEMBAHASAN}

"Pelatihan merupakan serangkaian aktivitas individu dalam meningkatkan keahlian dan pengetahuan secara sistematis sehingga mampu memiliki kinerja yang profesional di bidangnya, pelatihan juga sebagai proses pembelajaran yang memungkinkan pegawai melaksanakan pekerjaan yang sekarang sesuai dengan standar", Widodo (2015:82).

Hasil dari kegiatan penyuluhan dan pelatihan yang di lakukan oleh dosendosen Fakultas Ekonomi Universitas Pamulang dapat berguna bagi para karyawan CV. Enigma dalam rangka meng-upgrade kompetensi para peserta dalam hal pengelolaan konflik. Dengan diadakannya kegiatan tersebut, para peserta dapat memperoleh pengetahuan terkait konflik kerja dan cara mengatasinya, bagaimana cara mengelola kecerdasan emosi dalam menangani konflik, serta kemampuan bernegosiasi dalam menghindari konflik.

Para peserta juga dapat bercerita mengenai konflik yang mereka hadapi dan sering ditemukaan saat bekerja. Sehingga pada sesi sharing ini, tim penyuluh dan peserta dapat saling bertukar pikiran dalam menemukan solusi terbaik untuk konflik-konlik kerja yang sedang dialami.

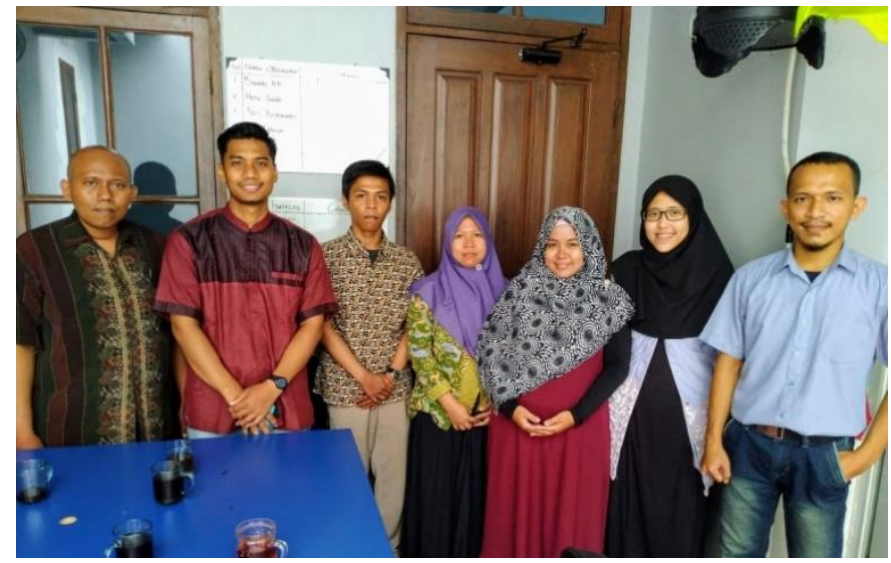

\section{Gambar 1. Silaturahim dengan bagian kepegawaian CV. Enigma}

Sebelum memulai kegiatan penyuluhan dan pelatihan yang dilakukan oleh dosen-dosen Fakultas Ekonomi Universitas Pamulang terlebih dahulu bersilaturahim ke kantor CV. Enigma. tujuan dari silatuharim adalah meminta izin kepada bagian kepegawaian untuk mengadakan kegiatan Pengabdian kepada Masyarakat yang berjudul "Mengelola Konflik Dalam Organisasi Untuk Menunjang Efektivitas Kerja Karyawan CV. Enigma”. 


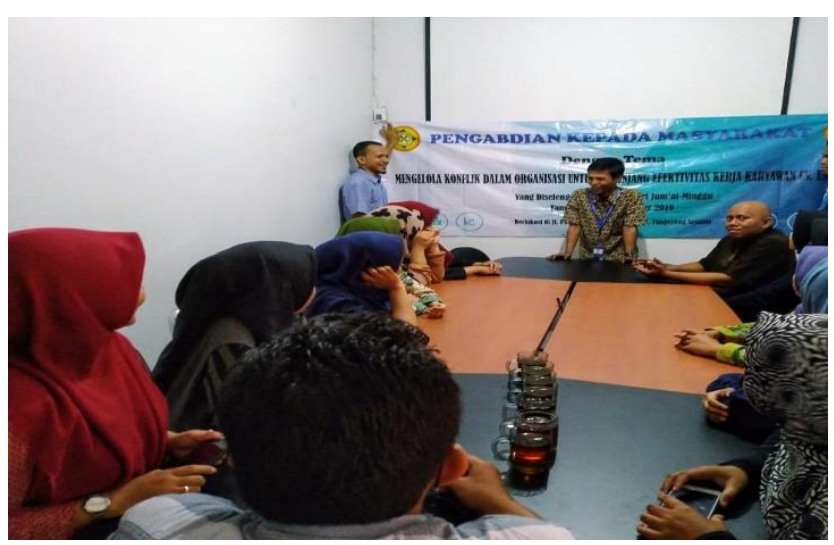

Gambar 2. Pemberian Materi dan Tanya Jawab dengan Para Peserta

Kegiatan pada gambar di atas, Anggada Bayu Seta, S.E., M.M. selaku narasumber sedang menyampaikan materi dan membuka sesi tanya-jawab bagi para peserta pelatihan yakni karyawan CV. Enigma. Selain itu, pada kegiatan ini para peserta bisa bercerita terkait konflik kerja yang sering ditemukan dan yang sedang dihadapi guna mencari solusi bersama. Hal ini dimaksudkan supaya apabila para peserta dihadapkan kembali dengan konflik yang sama, mereka sudah mengetahui bagaimana cara menanganinya dengan baik dan benar.
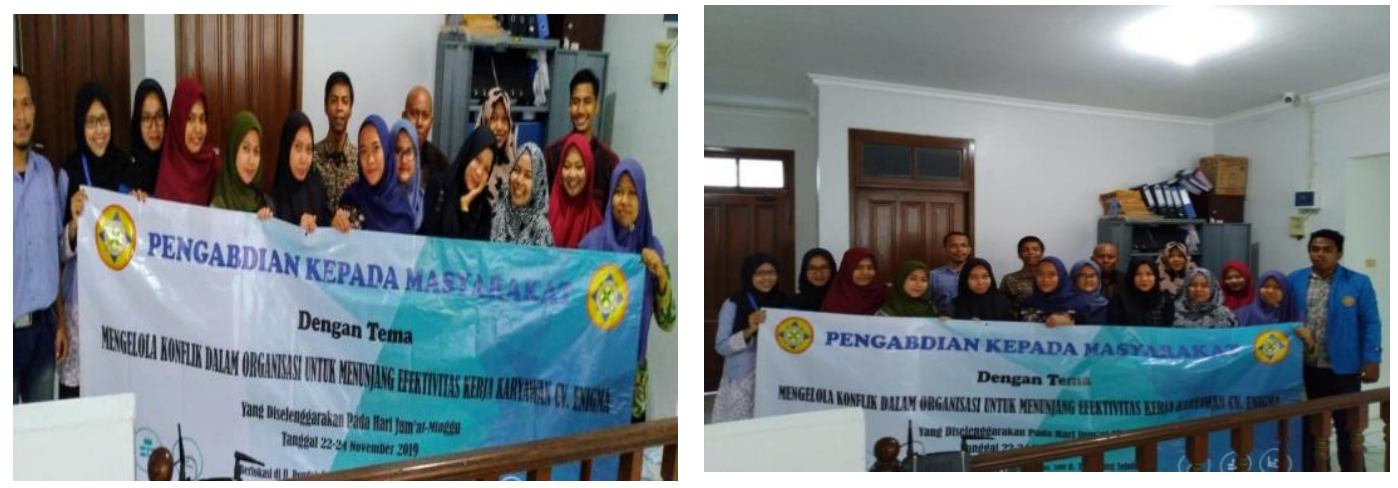

Gambar 3. Foto Bersama Setelah Kegiatan Penyuluhan dan Pelatihan

Adapun gambar di atas adalah sesi foto bersama dan kegiatan ramah tamah setelah kegiatan penyuluhan dan pelatihan yang di lakukan telah selesa.

\section{KESIMPULAN DAN SARAN}

Kegiatan penyuluhan dan pelatihan yang di berikan oleh dosen-dosen Fakultas Ekonomi Universitas Pamulang dapat memberikan dampak yang positif bagi para karyawan CV. Enigma selaku peserta. Seluruh peserta antusias dalam mengikuti rangkaian kegiatan acara. Mulai dari pemberian materi, melakukan permainan simulasi dinamika kelompok, serta saat berada pada sesi tanya dan jawab.Pertanyaan yang diajukan terkait konflik-konflik yang sering di jumpai saat 
bekerja, serta solusi mengenai cara mengelola konflik tersebut supaya dapat bersifat positif dan tidak mengganggu proses kerja yang sedang berlangsung.

\section{DAFTAR PUSTAKA}

Feriyanto, Andri dan Triana, Endang, Shytya. 2015. Komunikasi Bisnis (Strategi Komunikasi dalam Mengelola Bisnis). Yogyakarta: Pustaka Baru Press.

Sunarsi, D., \& Kusjono, G. (2019). Pengaruh Lingkungan Kerja Non Fisik, Konflik Dan Turn Over Intention Terhadap Produktivitas Kerja Karyawan Pada CV. Usaha Mandiri Jakarta Selatan. Jurnal Ekonomi Efektif, 1(3).

Wahyudi. 2011. Manajemen Konflik dalam Organisasi - Cetakan Keempat. Bandung: CV. Alfabeta.

Eko, Widodo, Suparno. 2015. Manajemen Pengembangan Sumber Daya Manusia. Yogyakarta: Pustaka Pelajar.

Wirawan. 2010. Konflik dan Manajemen Konflik, Teori, Aplikasi, dan Penelitian. Jakarta: Salemba Humanika. 